\title{
Preparing individuals to leave the institutional care from the perspective of the directors of the children's homes
}

\section{Tomáš Čech, Veronika Štenclová}

\begin{abstract}
There are two models of alternative family care in the Czech Republic - foster care is the most suitable when the child grows up in a substitute family. Children who cannot be placed in families are placed in a substitute institutional care, the function of which in the Czech Republic is fulfilled by children's homes intended for children aged 3 to 18 years. The aim of the research is to map the conditions and procedures for preparing children to leave children's homes from the point of view of the directors of these establishments.

The basic research sample consisted of 131 directors of state-run children's homes; the selection sample included 98 directors. A questionnaire was constructed and in order to ensure a high degree of reliability of the research tool and validity of the results obtained, it was triangulated by several independent experts.

The main finding based on the responses of the directors of children's homes is the fact that preparing children for leaving institutional care is a very challenging process with uncertain success. This process is not systematically treated by the state, and significant responsibility is transferred to children's homes and their staff. Selected children's homes have their own strategy for preparing children for independence and their successful integration in society; others consider it a continuous process in the context of regular childhood education. Many children's homes use cooperation with selected non-profit organizations to focus systematically on children leaving these establishments.
\end{abstract}


Key words: directors of children's homes, child in institutional care, preparation for independent living.

\title{
Příprava jedinců na odchod $z$ institucionální péče z perspektivy ředitelů dětských domovů
}

\begin{abstract}
Abstrakt
V České republice existují dva modely náhradní rodinné péče, kdy pěstounská péče je nejvhodnější, jelikož dítě vyrůstá v náhradní rodině. Děti, které nelze umístit do rodin, jsou umístěny do náhradní ústavní péče, jejiž funkci v České republice plní dětské domovy určené pro děti ve věku od 3 do 18 let. Cílem výzkumu bylo zmapovat podmínky a postupy prípravy dětí na opuštění dětských domovů z pohledu ředitelů těchto zařízení.

Základní soubor pro výzkum tvořilo 131 ředitelů státních dětských domovů; výzkumný soubor zahrnoval 98 ředitelů, kteří se zapojili do výzkumu. Byl sestaven dotazník, který byl za účelem zajištění vysoké míry spolehlivosti výzkumného nástroje a platnosti získaných výsledků triangulován několika nezávislými odborníky.

Hlavním zjištěním, založeným na odpovědích ředitelů dětských domovů, je skutečnost, že prýprava dětí na odchod z ústavní péče je velmi náročný proces s nejistým úspěchem. Stát tento proces systematicky neřeší a významná odpovědnost se přenáší právě na dětské domovy a jejich zaměstnance. Některé dětské domovy mají vlastní strategii pro prípravu dětí na samostatný život a jejich úspěšnou integraci do společnosti; jiné to považují za kontinuální proces v kontextu systematické výchovy dítěte. Mnoho dětských domovů využívá spolupráce s vybranými neziskovými organizacemi, které se systematicky zaměřují na podporu rozvoje dětí opouštějící tyto instituce.
\end{abstract}

Klíčová slova: ředitelé dětských domovů, dítě v ústavní péči, príprava na samostatný život.

DOI: 10.5507/epd.2021.023

\section{Institutional substitute family care in the Czech Republic}

In the system of Czech education, children's homes represent one of the types of establishments for children who cannot grow up in their families due to various circumstances. These children live in children's homes (referred to as $\mathrm{CH}$ ) for various periods 
of time, some stay until they come of age (18 years of age in the Czech Republic). For many people, this age is an imaginary transition to adulthood, which includes gaining of independence and taking full responsibility for oneself and one's life. An individual who grows up in $\mathrm{CH}$ may after coming of age terminate the stay at his/her own request. Or the individual may stay in $\mathrm{CH}$ even after coming of age. However, a precondition is continuous preparation for future career. In such case the person usually concludes a written agreement, thereby establishing the so-called agreement residence. Children's homes provide full board and lodging to individuals until they reach 26 years of age under specific conditions specified in the agreement. Although these individuals remain with friends and familiar people, this is still a temporary solution and one day they will have to leave the gates of $\mathrm{CH}$.

Gaining of independence among young adults who grow up in these establishments differs in many respects from those individuals who leave their families. The main difference consists primarily in the strategy of planning the process of leaving home and preparing for it. In the biological family, this strategy is more of an unconditional nature; individuals prepare for their independent life in a continuous and unorganized way and expect their families to help.

Young adults leave $\mathrm{CH}$ without a deeper preparation for what independent life involves and what they might expect, and this important step in their life is performed without reliance on their biological family. It is also for this reason that children with ordered institutional care are one of the four subgroups of a large group of socially disadvantaged individuals within Czech education (Němec, Vojtová, 2009).

Previous studies (Hanáková, Kormaňák, 2015; Matoušek, Pazlarová, Baldová, 2008; Gjuričová, 2007) point to a problem of insufficient preparedness of young adults to leave $\mathrm{CH}$, which in many cases leads to various life failures (drug addiction, prostitution, theft, etc.) According to the UN (2009), residential establishments should ensure full integration in society especially by the development and adoption of social and life skills, mastery of which significantly contributes to successful integration of the child in independent life. However, according to Musil (2008) the development of social skills is complicated for example by the institutional addiction syndrome, which means that clients get used to artificial institutional conditions and have a decreased ability to adapt to usual life. Institutions provide food, finance, daily regimen, accommodation. Later in life, these individuals are unable to satisfy their needs and cope with everyday situations such as ensuring material needs, arrangement of the daily regimen, searching for a job or a place to live, financial management (cf. Kim, López, Han, 2019), or communication with authorities. The usual cause of problems that individuals encounter after leaving residential establishments is insufficient experience with life outside the establishment, which results in unreal ideas about their independent life and expectations, a low level of education, and insufficient social competences (Matoušek, Pazlarová, Baldová, 2008).

The inability to achieve a successful personal development results in a crisis, which Macek (2003) considers a conflict between biological, psychological and social aspects. 
This conflict leads to a disruption or absence of moral attitudes and opinions, relationship with the surrounding world, self-reflection and self-conception.

Children's homes should have a clear policy and approved procedures that would in the case of planned or unplanned termination of children's stay ensure adequate follow-up care. Throughout the whole period of children's stay in children's homes, these establishments should systematically prepare these individuals for self-reliance and full integration in society, especially through development and acquisition of social and life skills, because the degree of their mastery significantly predicts the success of integration of the child in independent life (UN, 2009).

\section{Preparation for children's departure from children's homes - theoretical and research background}

Preparation for an independent life is an important stage of the social and rehabilitation process in residential establishments, and so far has not been given sufficient research attention.

In the Czech Republic, the issue of institutional establishments was mentioned by many authors (Procházka, 2009; Musil, 2008; Škoviera, 2007; Kovařík, Bubleová \& Šlesingerová, 2004; Matoušek, 1999, etc.) However, there are not many research studies on the topic. Existing research studies on the integration of individuals leaving institutional establishments have addressed this issue with various objectives and from various perspectives.

Probably the latest research was conducted between 2012 and 2015 by Hanáková and Kormaňák from Ipsos, an agency specialized in market research and public opinion polls in the Czech Republic. The research focused on children's concerns and ideas before leaving the children's home. The research was of a mixed design. In the qualitative part, interviews were made with 27 individuals 1-6 years after leaving the children's home, who had been forced to return and ask for help after a failed attempt to integrate in society. The quantitative part used a questionnaire and focused on 102 children one year or less before leaving the children's home. The main objective was to emphasise the insufficient preparedness of children to leave institutional establishments, which was primarily caused not by the children's homes but rather the state.

The key findings of the survey point to three major interconnected issues, which make the situation difficult for individuals leaving their children's homes. These issues include the following: 1) Insufficiencies in the system and education, 2) Lack of information about non-profit organizations and insufficient financial literacy, 3) Relationships - children from children's homes are excessively fixed on their carers (Hanáková \& Kormaňák, (02015). 
Although internationally the issue of leaving residential establishments is addressed by more authors than in the Czech Republic (Schofield, Larsson \& Ward, 2016; Adley \& Kina, 2014; Berridge, 2014; Refaeli, Benbenishty \& Eliel-Gev, 2013; Holt Kirwan, 2012; Dinisman \& Zeira, 2011; Sulimani-Aidanm \& Benbenishty, 2011; Höjer \& Sjöblom, 2009; Stein, 2006, 2012; Cashmore \& Paxman, 2006; Howe, 1997, etc.), it should be noted that there are differences in the systems of substitute family care and institutional care between foreign countries and the Czech Republic. Despite these cultural, social or economic nuances, it is possible to draw some inspiration from these foreign approaches.

Relevant Czech legislation addresses the issue of children leaving residential establishment in a very curt manner despite the extensiveness of the issue. This area is addressed only by two Acts.

Act No. 109/2002 Coll. On the execution of institutional and protective education in school establishments and on preventive educational care in school establishments briefly mentions the responsibility of directors of children's homes to contact a social custodian at least six months before a child leaves the establishment. Their role is especially to provide advice and information about the options that the clients have outside the establishment. There is a problem however with children's trust in custodians. Children meet custodians in a very limited manner, know them very little, and their relationship lacks trust. The act also stipulates that individuals who come of age and leave the establishment shall be entitled to a material or single financial contribution of CZK 15,000 (about \$ 700) according to their actual needs at the time of discharge and in compliance with applicable internal regulations.

Act No. 359/1999 Coll. On social and legal protection of children stipulates a different provision. This act provides information about discharging children from institutional education and stipulates that children's establishments are obliged to inform the district authority about an upcoming discharge of a child. The act also stipulates that regional authorities are obliged to help children who completed school attendance in searching for opportunities to prepare for their future career; this primarily applies to children discharged from institutional education, protective education, or after imprisonment.

However, the acts do not define any procedures for preparing individuals to leave these establishments in order to ensure successful social integration.

\section{Methodology of Research}

The research study focuses on the phenomenon of individuals leaving children's homes. This area is given insufficient attention in the Czech Republic and there is no generally accepted definition of the methods and approaches of effective preparation of clients for leaving residential establishments to ensure their successful social integration 


\subsection{General Background of Research}

The research study focusing on children leaving children's homes includes several stages. The present paper reflects on the first quantitative part, the main objective of which is to map and describe the situation relating to the preparation of individuals for leaving children's homes to become independent.

The partial objectives of the quantitative part of the research are as follows:

- To define the specifics of preparing children to leave children's homes to become independent.

- To identify the prevailing methods of working with children in preparing them to leave children's homes and in preparing them for an independent life.

- To describe the core aspects that affect the preparation to leave children's homes.

In accordance with the objectives was formulated the main research question in as follows:

How do the directors of children's homes assess the system of state support concerning the preparation of children to leave children's homes?

In relation to the main research question, a total of three hypotheses were defined. The hypotheses were formulated as alternative hypotheses regarding the limitation consisting in the real number of respondents (see Research sample). The purpose of the hypotheses was to test the relationship between the assessment of the system by the directors and the circumstances that may affect this assessment and the work of children's homes in preparing children to leave institutional care (relationship with the biological family, joining the biological family after leaving the children's home, size of the place where $\mathrm{CH}$ is located). The hypotheses were formulated as follows:

H1: There is a statistically significant difference between the assessment of the system of preparation of children to leave children's homes by the directors and children's attitude to the biological family as a limiting factor.

H2: There is a statistically significant difference between the assessment of the system of preparation of children to leave children's homes by the directors and children joining their biological families after leaving the children's home.

H3: There is a statistically significant difference between the assessment of the system of preparation of children to leave children's homes by the directors and the size of the location where the children's home is located. 
For the purposes of the present paper, the following secondary research questions were defined (to describe the directors' experience):

- When do children's homes start the process of preparation of children to leave?

- What are the methods of working with clients that children's homes use in their preparation to leave children's homes?

- What are the limitations in working with children in their preparation to leave the children's home?

\subsection{Sample of Research}

In the Czech Republic there are 142 children's homes. 2 children's homes are run by the Ministry of Education, 6 children's homes are private, 3 children's homes are run by the Church, and the remaining 131 establishments are within the competence of relevant regional authorities.

During the first stage of the research, the leading employees of children's homes run by regional authorities in the Czech Republic were addressed. Before the questionnaires were sent, these children's homes were contacted via telephone and asked whether the questionnaire can be sent to them. In this way, the entire research sample consisting of 131 children's homes was addressed. Those children's homes that are not operated by regional authorities were deliberately excluded from the research sample due to their different regimen and methods of working with children.

For the purposes of the present paper the researchers processed a total of 98 questionnaires completed by directors of children's homes (final sample, return rate $75 \%$ ).

\subsection{Instrument and Procedures}

The key method of the quantitative part of the research was a questionnaire designed by the authors consisting of 21 items.

The questionnaire was divided into several sections by the type of information required. These sections focused on the following topics:

- System of preparation of children to leave the children's home on the part of the state in the Czech Republic.

- Preparation of children to leave the children's home on the part of the children's home.

- Limitations in the preparation of children to leave the children's home.

- Information relating to children after they leave the children's home.

- Demographic data.

Item 21 was of a qualitative nature and provided space for free responses concerning the topic of the research. 
In a preliminary study, the researchers analysed the reliability of the research instrument by means of triangulation of consultations with selected professionals in the area of methodology and statistics. As far as content validity is concerned, the questionnaire was consulted with the directors of the children's homes. After the preliminary study, some of the questionnaire items were modified and reformulated to become more comprehensible to the respondents.

\subsection{Data Collection and Analysis}

The data for statistical processing were collected by means of a questionnaire survey. First the questionnaire was developed in a printed form and then converted into an online form. Regarding the different availability of the respondents in the Czech Republic, this method appeared as most suitable. The questionnaire was sent as an online link via e-mail communication. The respondents were also contacted via telephone to be explained the objectives of the research, the results of which should help children's homes with the process of preparation of children to leave institutional care and increase the effectiveness of integration of these adult individuals in society.

As has already been mentioned, the paper reflects on the first stage of the research, which focused on initial information concerning the preparation of children to leave children's homes. At this point, the key aspect is to describe the situation in the area. Therefore, the outcomes are exclusively of a descriptive nature. The focus of the present paper was on the assessment of the system of preparation of adolescents by the directors and the effect of relevant variables.

In the first stage, the data were transformed into an xls format compatible with MS Excel 2013, which can easily handle data exported from the electronic questionnaire. In the second stage, the data were formally and logically checked and processed by STATISTICA, version 13. The relationships between the variables were verified by the chi-squared test; the tests were performed at a $5 \%$ level of significance.

\section{Results of Research}

The following section describes the key findings identified on the basis of a questionnaire survey conducted in 98 children's homes in the Czech Republic. These findings are presented in several subchapters in compliance with the research objectives and research questions.

The very first task of the research study was to answer the following research question: How do the directors assess the system of state support concerning the preparation of children to leave children's homes? 


\section{Table 1}

Assessment of the system of state support concerning the preparation of children to leave $\mathrm{CH}$

\begin{tabular}{|l|c|c|c|c|}
\hline \multirow{2}{*}{ Category } & \multicolumn{4}{|c}{$\begin{array}{c}\text { Frequency table: } 1 \text {. In your opinion, the system of state support concerning } \\
\text { the preparation of children to leave CH in the Czech Republic is: }\end{array}$} \\
\cline { 2 - 5 } & Count & Cumulative Count & Percentage & Cumulative Percent \\
\hline Completely unsatisfactory & 18 & 18 & 18.36735 & 18.3673 \\
\hline Partially unsatisfactory & 50 & 68 & 51.02041 & 69.3878 \\
\hline Partially satisfactory & 25 & 93 & 25.51020 & 94.8980 \\
\hline $\begin{array}{l}\text { Completely satisfactory } \\
\text { and sufficient }\end{array}$ & 5 & 98 & 5.10204 & 100.0000 \\
\hline Missing & 0 & 98 & 0.00000 & 100.0000 \\
\hline
\end{tabular}

Figure 1

Assessment of the system of state support concerning the preparation

of children to leave $\mathrm{CH}$

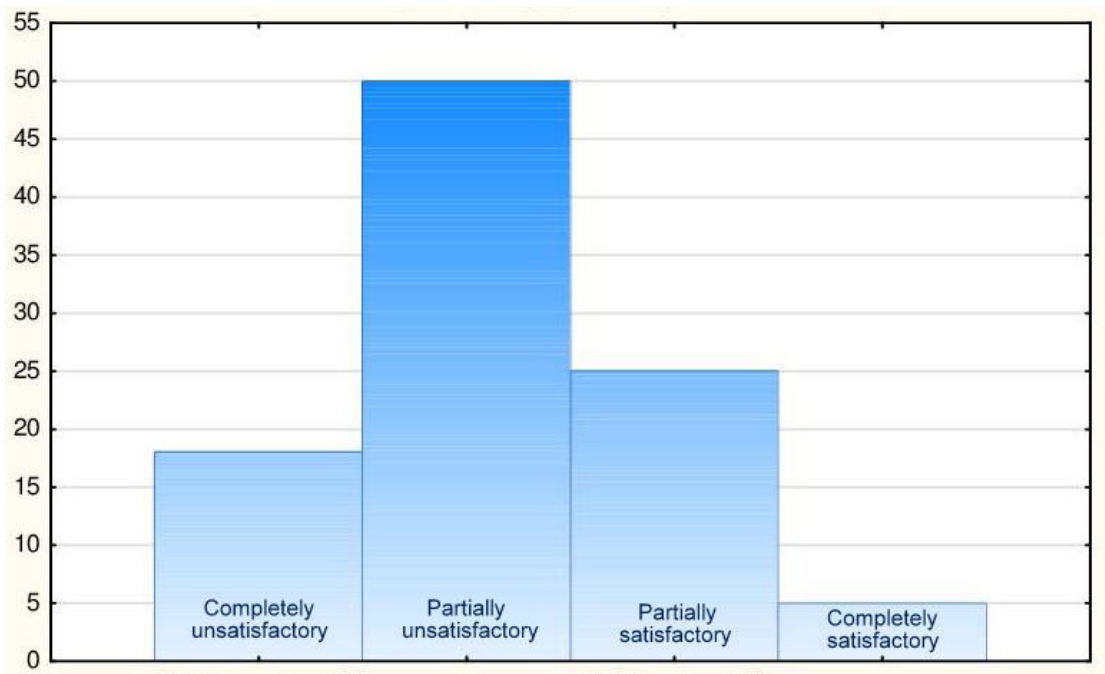

Table 1 and Figure 1 clearly show that the system of support is assessed as unsatisfactory by $69 \%$ of the directors; specifically as completely unsatisfactory by $18 \%$ of the directors and as partially unsatisfactory by $51 \%$ of the directors. $31 \%$ assess the state system as partially satisfactory and only $5 \%$ as completely satisfactory. 
The next stage focused on the relationship between the assessment of the system and the factors that may affect this assessment and the work of children's homes in preparing children to leave institutional care. Special attention was paid to the relationship between the child and the biological family during the child's stay in the children's home as a limiting factor, the child after leaving substitute family care and returning to the biological family, and last but not least the size of the place where the children's home is located.

H1: There is a statistically significant difference between the assessment of the system of preparation of children to leave children's homes by the directors and children's attitude to the biological family as a limiting factor.

\section{Table 2}

Relationship between the assessment of the system of preparation and the attitude of the child to the biological family

\begin{tabular}{|c|c|c|c|}
\hline \multicolumn{4}{|c|}{$\begin{array}{l}\text { Summary Table: Expected Frequencies } \\
\text { Marked cells have counts }>10 \text { Pearson Chi-square: } .724222, \mathrm{df}=1, p=.394763\end{array}$} \\
\hline $\begin{array}{l}\text { Assessment of preparation of children to leave } \mathrm{CH} \\
\text { versus attitude to the biological family of the child }\end{array}$ & $7 f 0$ & $7 f 1$ & Row Totals \\
\hline Negative & 18.73469 & 49.26531 & 68.00000 \\
\hline Positive & 8.26531 & 21.73469 & 30.00000 \\
\hline All Grps & 27.00000 & 71.00000 & 98.00000 \\
\hline
\end{tabular}

The effect of the attitude to the biological family of the child on the assessment of the system of preparation of children to leave children's homes was not confirmed and therefore, alternative hypothesis 1 is refuted. The difference in the responses was not statistically significant $\left(x^{2}=0.724,, p=.394\right)$. However, the greatest percentage difference was observed among those directors (75\%) who assessed the system of preparation of children to leave $\mathrm{CH}$ as unsatisfactory and the attitude of the child to the biological family as a limiting factor, although the difference is not statistically significant. H2: There is a statistically significant difference between the assessment of the system of preparation of children to leave children's homes by the directors and children joining their bilogical families after leaving the children's home. 
Table 3

Relationship between the assessment of the system of preparation and the child joining the biological family after leaving $\mathrm{CH}$

\begin{tabular}{|l|c|c|c|}
\multicolumn{4}{|c|}{$\begin{array}{l}\text { Summary Table: Expected Frequencies } \\
\text { Marked cells have counts }>10 \text { Pearson Chi-square: } .010370, \mathrm{df}=1, \mathrm{p}=.918891\end{array}$} \\
\hline \begin{tabular}{l|c|c|}
\hline Assessment of preparation of children to leave $\mathrm{CH}$ \\
versus the child joining the biological family
\end{tabular} & $8 \mathrm{a} 0$ & $8 \mathrm{a} 1$ & Row Totals \\
\hline Negative & 13.18367 & 54.81633 & 68.00000 \\
\hline Positive & 5.81633 & 24.18367 & 30.00000 \\
\hline All Grps & 19.00000 & 79.00000 & 98.00000 \\
\hline
\end{tabular}

The effect of children joining the biological family after leaving $\mathrm{CH}$ on the assessment of the system of preparation of children to leave children's homes was not confirmed and therefore this hypothesis is refuted. The difference in the responses was not statistically significant $\left(X^{2}=0.010, p=.918\right)$. However, the greatest percentage difference $(88.88 \%)$ was observed in the directors who assessed the system of preparation of children to leave $\mathrm{CH}$ as unsatisfactory, which suggests that the return of children to their biological family after leaving the children's home can be considered a systematic problem because this target group has limited opportunities to be included in society. Therefore, their return to this risky environment is considered a systematic problem.

H3: There is a statistically significant difference between the assessment of the system of preparation of children to leave children's homes by the directors and the size of the location where the children's home is located.

\section{Table 4}

Relationship between the assessment of the system of preparation and the attitude of the child to the biological family and the size of the municipality where $\mathrm{CH}$ is located

\begin{tabular}{|c|c|c|c|c|c|}
\hline \multicolumn{6}{|c|}{$\begin{array}{l}\text { Summary Table: Expected Frequencies } \\
\text { Marked cells have counts }>10 \text { Pearson Chi-square: } 2.18916, \mathrm{df}=3, \mathrm{p}=.534087\end{array}$} \\
\hline $\begin{array}{l}\text { Assessment of preparation } \\
\text { of children to leave } \mathrm{CH}\end{array}$ & $\begin{array}{l}\text { Up to } 1,999 \\
\text { inhabitants }\end{array}$ & $\begin{array}{l}2,000-9,999 \\
\text { inhabitants }\end{array}$ & $\begin{array}{l}10,000-49,999 \\
\text { inhabitants }\end{array}$ & $\begin{array}{l}\text { More than } 50,000 \\
\text { inhabitants }\end{array}$ & Row Totals \\
\hline Negative & 17.44792 & 26.52083 & 13.26042 & 9.77083 & 67.00000 \\
\hline Positive & 7.55208 & 11.47917 & 5.73958 & 4.22917 & 29.00000 \\
\hline All Grps & 25.00000 & 38.00000 & 19.00000 & 14.00000 & 96.00000 \\
\hline
\end{tabular}

The effect of the size of the place where $\mathrm{CH}$ is located on the assessment of the system of preparation of children to leave children's homes was not confirmed. The difference in the responses was not statistically significant $\left(x^{2}=2.18, p=.53\right)$. However, the great- 
est percentage difference was observed in those directors who assessed the system of preparation of children to leave $\mathrm{CH}$ as unsatisfactory in smaller towns of up to 9,999 inhabitants (41.79\%). This confirms the assumption that directors from smaller towns are more concerned about children leaving for 'a great world', which is often a big city posing a number of threats for young adults after their departure from institutional care as described in the research (housing problems, homelessness, financial problems, greater concentration of risk groups, risk of criminal behaviour, etc.)

The next stage of the research defines the ways that children's homes work, and provided an answer to the partial research question What are the methods of working with clients that children's homes use in their preparation to leave children's homes? In the context of mapping the prevailing forms of work with children in children's homes focusing on their leaving and preparation for an independent life, the authors focused on the activities of the staff of children's homes and the contribution of the non-profit sector (see Table 5).

\section{Table 5}

Beginning of systematic preparation of children to leave children's home

\begin{tabular}{|c|c|c|c|}
\hline \multicolumn{4}{|c|}{ Frequency table: 5. Describe the way of systematic preparation of children to leave $\mathrm{CH}$} \\
\hline Count & Cumulative Count & Percentage & Cumulative Percent \\
\hline 58 & 58 & 59.18367 & 59.1837 \\
\hline 15 & 73 & 15.30612 & 74.4898 \\
\hline 4 & 77 & 4.08163 & 78.5714 \\
\hline 20 & 97 & 20.40816 & 98.9796 \\
\hline 1 & 98 & 1.02041 & 100.0000 \\
\hline
\end{tabular}

It shows information regarding the time that children's homes allocate to the preparation of children to leave the establishment. A majority of children's homes included in the study (59.2\%) do not distinguish between preparation of children for an independent life and usual educational activities. This approach could be compared to usual families, where children prepare for leaving the family in an unconditional, continuous and unorganized way. Far fewer respondents $(20.5 \%)$ believe that this preparation is a specific activity, which takes place at least one year before the child comes of age, irrespective of whether the person continues study or not. 15.3\% of children's homes apply this activity at least one year before the expected departure of the child (due to coming of age or termination of systematic preparation for a future career). Only 1 children's home does not focus on the preparation of children to leave at all.

This preparation takes various strategic dimensions that differ by children's homes. Figure 2 shows that the most frequent strategy used in children's homes is setting of 
a specific regimen to those children who are about to leave the establishment. This was indicated by $80.7 \%$ of the respondents. Such specific regimen includes for example living in flats or other types of urban development separated from the rest of the children's home. In this way, the individuals use their own forces and become more independent. The specific regimen also includes an emphasis on accepting greater responsibility for oneself and one's own conduct.

Figure 2

Method of preparation of children to leave children's home

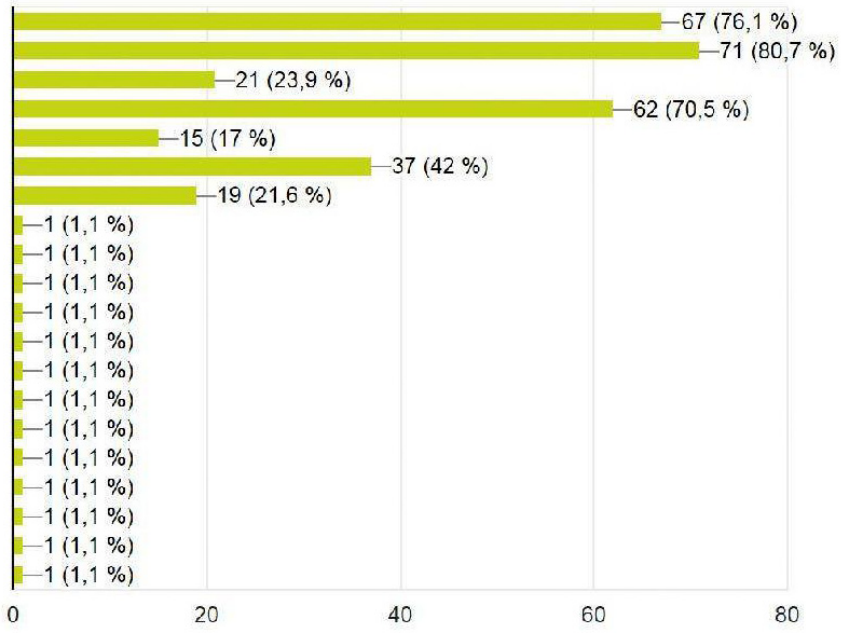

According to $76.1 \%$ of the directors, another frequently used approach to working with children is systematic meetings with the child and addressing issues related to leaving the children's home. The third most frequent method (70.5\%) is cooperation between children's homes and the non-profit sector. These non-profit organizations focus on the development and implementation of programmes and projects that facilitate children's departure from children's homes. In the Czech Republic the cooperation with these organizations or participation in their projects is not mandatory, and therefore children's homes use them at their discretion and according to their needs. Of the total of 98 children's homes included in the research, only 21 do not use services provided by non-profit organizations.

The remaining 77 children's homes and their clients are involved in projects focusing on financial literacy, strengthening of motivation, self-confidence and belief in one's own capabilities (more about the importance of self-confidence in adolescents e.g. 
Ďuricová, Frgelcová, 2020; 2018), job opportunities, self-care, or international language courses.

The last aspect assessed in the present paper concerns the limitations that according to the directors of children's homes affect the effectiveness of preparing children to leave institutional care. The research question is as follows: What are the limitations in working with children in their preparation to leave children's homes? Just as there are protective factors associated with the preparation of children to leave residential care, children's homes also encounter limitations that make the process of preparation impossible or difficult.

Figure 3

Limitations in working with children in their preparation to leave children's homes

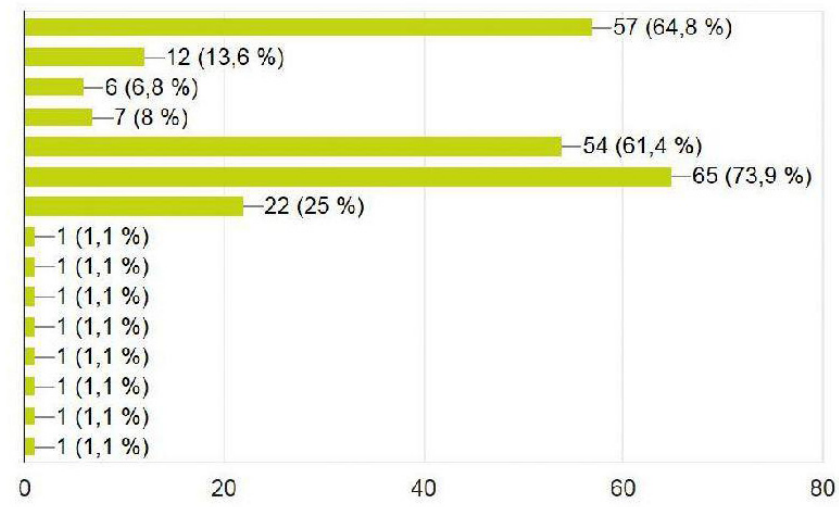

Figure 3 shows the limitations that children's homes encounter most frequently. Interestingly, $73.9 \%$ of the respondents believe that the greatest limitation is represented by ties to the biological family. Although it may seem absurd, in most cases a dysfunctional biological family is the cause why children are placed in an institution, and according to this study also the most frequent cause which makes it difficult for the staff in children's homes to prepare children for an independent life. $64.8 \%$ of the respondents suggest that a considerable limitation is the state support in systematic preparation. The vast majority of children's homes consider the system of state support in this area insufficient. The third most frequent limitation according to $61.4 \%$ of the respondents is disinterest and lack of motivation on the part of children. Children's homes try to address these aspects by their own efforts or in cooperation with non-profit organizations. The factor of the biological family or personality setting of the child resulting in insufficient motivation for successful integration in society is also caused by the children's ethnicity as confirmed by $25 \%$ of the respondents. 


\section{Conclusion}

The main finding from the directors of children's homes is the fact that preparing children for leaving institutional care is a very challenging process with uncertain success. This process is not systematically treated by the state and therefore the system of preparation of children to leave the children's homes is assessed by the directors as unsatisfactory (69\% of respondents). Therefore significant responsibility is transferred to the children's homes and their staff. Selected children's homes have their own strategy of preparing children for independence and their successful integration into society; others consider it a continuous process in the context of regular childhood education. Many of the children's homes use cooperation with selected non-profit organizations to focus systematically on children leaving the children's home. The effectiveness of the programs depends on the length of the cooperation, the level of funding in the project, both from the European Union grant programs and from private donors.

The process of preparing children for leaving a child's home and its success depends on a number of factors. One of them is the time when a child comes to a child's home it is the direct proportion between the life of the child in the risky environment of the biological family and the success of his preparation for leaving and then integrating into society. Other key factors include the intensity of contact with the biological family and its risky environment, and missing systematic support by the state. Last but not least, a significant factor is the low motivation of children for preparation for independent life, because most of them are unable to think about the future and are slightly deformed by the social system of institutional care, which provides everything and resolves all matters before they leave the children's home. Specific factor is the ethnicity of the child, because a significant proportion of children in institutional care in the Czech Republic are children of Roma ethnicity, which significantly affect the child's mentality and its distrust in the institutions of the majority society (schools, children's homes).

It is not possible to compare our results with other countries because the issue of alternative family care and institutional care is addressed specifically in all countries. Nevertheless, we believe that our knowledge can be beneficial to professionals in many countries dealing with related issues.

\section{Acknowledgements}

The study is dedicated to a specific project ZD-ZDOVA1-011 named "Primary prevention of mental disorders in children during young adolescence", which is financed from the European Economic Area Funds 2014-2021 (Norway Grants) and the state budget of the Czech Republic. 


\section{References}

Adley, N. \& Kina, J. V. (2014) Getting behind the closed door of care leavers: understanding the role of emotional support for young people leaving care. Dundee: University of Dundee.

Bittner, P. et al. (2007) Dèti z ústavư!: Právní a psychologické dopady ústavní výchovy z pohledu ochrany rodiny a nejlepšího zájmu dítěte. Brno: Liga lidských práv.

Čech, T. (2012). Dospívající v ústavní výchově a příprava na dospělost a život ve společnosti. In Vítková, M., Friedmann, Z. (eds.). Profesní orientace žáků se speciálními vzdělávacími potřebami. Vzdělávání žáků se speciálními vzdělávacími potrebami. Brno: Masarykova univerzita.

Duuricová, L., \& Frgelcová, E. Development of Self-concept in Slovak Adolescents. The New Educational Review, 60(2), 13-26.

Duuricová, L., \& Ladnová, Z. (2018). Perceived parenting style and self-concept of Slovak pubescent youth. The New Educational Review, 52(1), 55-65.

Gjuričová, J. (2007) Analýza stavu a dalšího vývoje mladých lidípo opuštění zařizení pro výkon ústavní nebo ochranné výchovy za období 1995-2004. Praha: MV a MŠMT.

Hanáková, L. \& Kormaňák, M. (2015) Jsou na odchod do běžného života prípraveny děti z dětských domovů? [cit. 2018-05-14]. IPSOS [online].

Holt, S., \& Kirwan, G. (2012) The "key" to successful transitions for young people leaving residential child care: The role of the keyworker. Child Care in Practice. 18(4), 371-392.

Kim, M. H., \& López, E. Y. (2019). Does Education Matter for the Earnings of Young Adults? The New Educational Review, 56(2), 172-183.

Macek, P. (1999) Adolescence: psychologické a sociální charakteristiky dospívajících. Praha: Portál.

Matoušek, O. (1999) Ústavní péče. 2. rozš. a přeprac. vyd. Praha: SLON.

Matoušek, O.; Pazlarová, H. \& Baldová, L. (2008) Individuální plánování služeb u ohrožených dětí a mládeže s dưrazem na mladistvé odcházející z ústavní výchovy. Praha: Člověk hledá člověka.

Mulheir, G. \& Browne, K. (2007) De-institutionalising and transforming children's services. A guide to good practice. Birmingham: University of Birmingham.

Musil, L. (2000) Osoby se syndromem ústavní závislosti a řešení jejich problému v Brně: podkladová studie pro koncepci Magistrátu města Brna. Brno: Fakulta sociálních studií MU.

Němec, J. \& Vojtová, V. (2009) Vzdělávání žákư se sociálním znevýhodněním. Brno: Paido.

Schofield, G., Larsson, B. \& Ward, E. (2016) Risk, resilience and identity construction in the life narratives of young people leaving residential care. Child \& Family Social Work, 22: 782-791. doi: $10.1111 /$ cfs.12295.

Stein, M. (2006) Research review: young people leaving care. Child and Family Social Work 11, 3, 273-279.

Stein, M. (2012) Young people leaving care: supporting pathways to adulthood. Philadelphia: Jessica Kingsley Publishers.

UN (2009). Směrnice o náhradní péči o děti [online]. [cit. 2018-05-14]. Dostupné na: <http//:www. msmt.cz>.

Zákon č. 109/2002 Sb. o výkonu ústavní výchovy nebo ochranné výchovy ve školských zařízeních a o preventivně výchovné péči ve školských zařízeních a o změně dalších zákonů (2002).

Zákon č. 359/1999 Sb. o sociálně právní ochraně dětí (1999). 


\section{Contacts:}

doc. PhDr. Tomáš Čech, Ph.D.

Palacký University in Olomouc, Faculty of Education

Institute of Education and Social Sciences

Žižkovo náměstí 5, 77900 Olomouc, Czech Republic

e-mail: tomas.cech@upol.cz

+420585635406

Mgr. Veronika Štenclová, Ph.D.

Palacký University in Olomouc, Faculty of Education

Institute of Education and Social Sciences

Žižkovo náměstí 5, 77900 Olomouc, Czech Republic

e-mail: veronika.stenclova@upol.cz

Doc. PhDr. Tomáš Čech, Ph.D. works at the Faculty of Education, Palacký University Olomouc, Institute of Education and Social Studies. His expertise and research focus on social pathology, prevention and intervention of risk behaviour and behavioural disorders in children and adolescents as well as leisure education. A significant part of his expertise also concerns school climate and relationships as well as school counselling. He conducted several research studies on bullying in the workplace and in the school setting. Between 2009 and 2017 he was the Chair of the Czech Educational Society, currently he is the Vice-Chair.

Mgr. Veronika Štenclová, Ph.D., is a graduate of a doctoral degree in Education at the Faculty of Education, Palacký University Olomouc, where she now participates in the project Primary prevention of mental disorders in children during young adolescence. For a number of years, she has also been an educator in a children's home and assistant professor at the Faculty of Education, University of Ostrava. Her expertise focuses on the process of education of children, youth and adults with signs of risk behaviour and on the education of individuals in institutional and protective care establishments with the aim of their reintegration. 